Original Research

Agrinula : Jurnal Agroteknologi dan Perkebunan 2021 vol. 4 (1): $22-26$

website : https://journal.utnd.ac.id/index.php/agri

E-ISSN : 2655-7673

DOI : https://doi.org/10.36490/agri.v4i1.108

NERACA KEHIDUPAN KUTU KEBUL (Bemisia tabaci Genn.) (HEMIPTERA: ALEYRODIDAE) PADA TANAMAN CABAI (Capsicum annuum L.)

\title{
LIFE BALANCE OF WHITEFLY (Bemisia tabaci Genn.) (HEMIPTERA: ALEYRODIDAE) IN CHILI PLANT (Capsicum annuum L.)
}

\section{Hazen Arrazie Kurniawan, \& Fitria*}

Program Studi Agroteknologi, Fakultas Pertanian, Universitas Muhammadiyah Sumatera Utara, Medan 20238, Sumatera Utara, Indonesia

*Koresponding author : fitria@umsu.ac.id

\begin{tabular}{|c|c|}
\hline Informasi Artikel & ABSTRAK \\
\hline $\begin{array}{l}\text { Disubmit: } \\
\text { 20 Desember } 2020 \\
\text { Direvisi: } \\
\text { 18 Januari } 2021 \\
\text { Diterima: } \\
\text { 23 Januari } 2021 \\
\text { Dipublikasi: } \\
\text { 23 Januari } 2021\end{array}$ & $\begin{array}{l}\text { - Pendahuluan: Bemisia tabaci merupakan salah satu } \\
\text { hama penting yang menyebabkan kerusakan langsung } \\
\text { dengan menghisap cairan tanaman. Tujuan penelitian ini } \\
\text { memberikan informasi neraca kehidupan hama Bemisia } \\
\text { tabaci pada tanaman cabai. } \\
\text { - Metode Penelitian: Penelitian ini dilaksanakan di } \\
\text { Laboratorium Fakultas Pertanian, Universitas } \\
\text { Muhammadiyah Sumatera Utara, Medan pada Januari } \\
\text { sampai Februari 2020. Tanaman yang digunakan dalam } \\
\text { pengujian ini adalah tanaman cabai varietas Keriting } \\
\text { Bogor umur tiga bulan. Pengujian neraca kehidupan } \\
\text { pada tanaman diawali dengan memasukkan } 15 \text { individu } \\
\text { imago B. tabaci (5 jantan dan } 10 \text { betina) ke dalam tabung } \\
\text { plastik. } \\
\text { Hasil Penelitian: kutu kebul yang melengkat di sungkup } \\
\text { berasal dari tanaman cabai memiliki morfologi panjang } \\
\text { sekitar } 0,2-0,3 \text { mm. Telur dimasukkan ke dalam jaringan } \\
\text { tanaman. Telur dibawah daun pada suhu } 26-32^{\circ} \mathrm{C} \text { masa } \\
\text { inkubasi berlangsung selama } 4-6 \text { hari, sedangkan pada } \\
\text { suhu } 18-22^{\circ} \mathrm{C} \text { meningkat menjadi } 10-16 \text { hari. } \\
\text { Kata Kunci: Bemisia tabaci; neraca kehidupan; tanaman } \\
\text { cabai }\end{array}$ \\
\hline
\end{tabular}

Agrinula : Jurnal Agroteknologi dan Perkebunan, 2021 vol. 4 (1): 22-26 


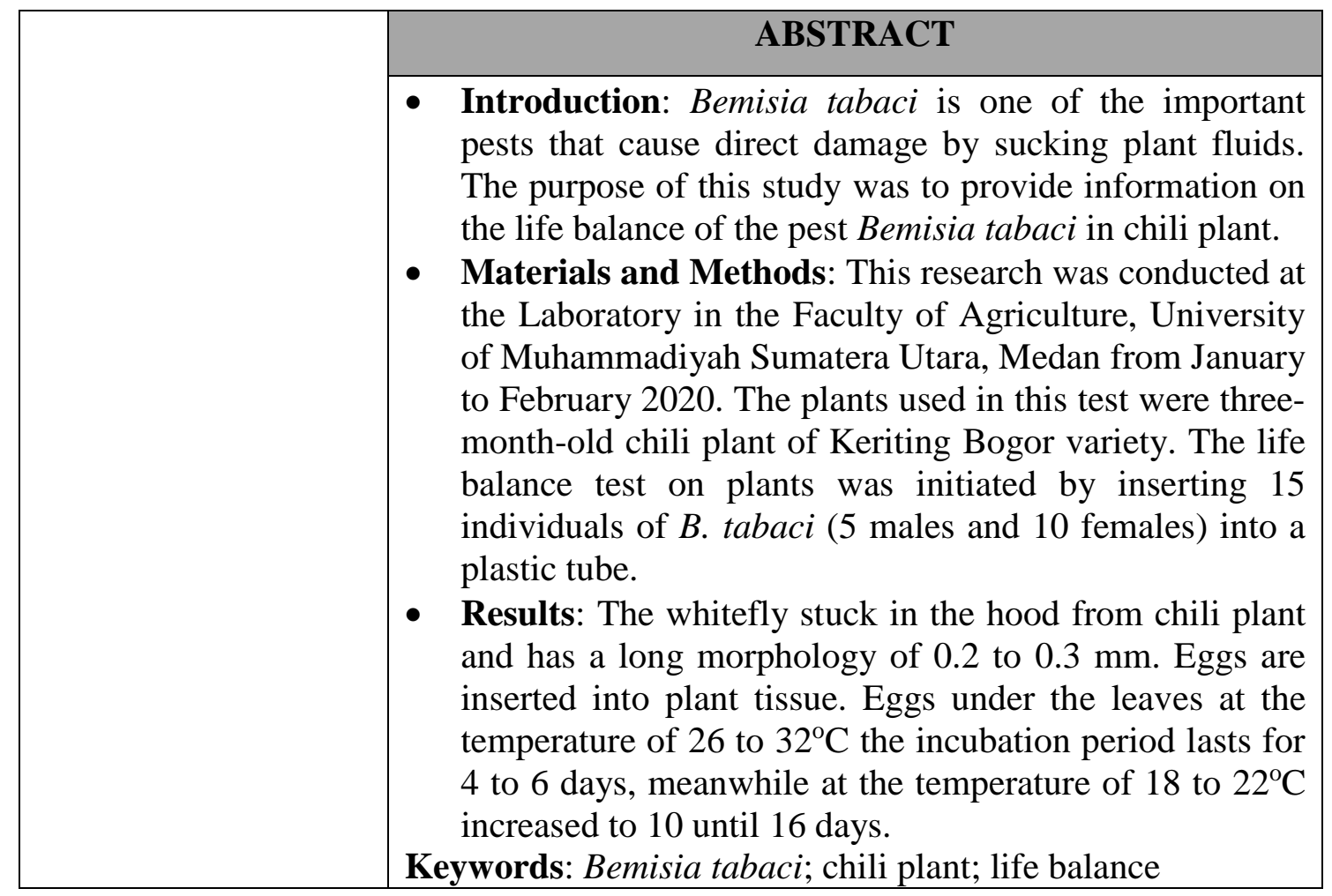

\section{PENDAHULUAN}

Sayuran merupakan tanaman hortikultura yang sangat penting dan mengandung banyak vitamin dan mineral serta serat, ada beberapa jenis sayuran yang sangat penting salah satunya mentimun dan cabai keduanya mempunyai nilai ekspor yang tinggi, terkadang hal ini terkendala oleh adanya factor penggangu terutam berkaitan dengan hama tanaman pada sayuran hama tersebut salah satunya B tabaci yang di ketahui dapat menimbulkan gagalnya panen di beberapa daerah di sumatera utara.

Bemisia tabaci (Gennadius) merupakan salah satu spesies kutu kebul yang berperan sebagai hama penting pada berbagai tanaman pertanian (Simala, 2009). Selain itu, B. tabaci juga memiliki kemampuan sebagai vektor tomato yellow leaf curl virus (TYLCV) yang umumnya menyerang pertanaman cabai di Indonesia. Kerusakan akibat TYLCV pada pertanaman cabai dapat menyebabkan kehilangan hasil panen $20 \%$ sampai 100\% (Sudiono, 2003).

Kutu kebul (Bemisia tabaci) bias disebut juga kutu putih, secara internasional dikenal dengan silverleaf whitefly, merupakan hama dari lalat putih kutu kebul hama yang sangat sulit di atasi karena hama di lindungi oleh lapisan tepung lilin yg tebal dan sulit di basahi. Tanaman Inang yang dipengaruhi oleh kutu kebul sangat beranekaragam mencakup tanaman sayuran seperti: tomat, labu, mentimun, terong, okra, buncis dan kacang-kacangan, brokoli, kembang kol, kubis, melon, kapas, wortel, ubi jalar, dan sayuran lainnya. Tanaman hias pun tak luput dari serangan, seperti mawar, poinsettia, krep murad, lantana, lili, dan lain-lain. tak luput dari serangannya. Serangga ini sering membuat masalah terutama sebagai parasit yang mengambil makanan dari tanaman inangnya, dengan cara menusuk floem atau permukaan daun bawah dengan mulut dan 
menghisap nutrisi di dalamnya. Daerah yang terkena dapat memunculkan klorosis setempat. Lalat putih juga menghasilkan sekresi/zat lengket yang disebut embun jelaga (honeydew) atau embun madu yang tertinggal pada inang, biasanya menutupi permukaan daun bagian bawah. Embun ini dapat menyebabkan pertumbuhan jamur jelaga, yang akhirnya akan mengurangi kemampuan tanaman untuk menyerap cahaya. Alhasil pertumbuhan tanaman menjadi terhambat, hasil panen rendah dan kualitas buruk. Hal ini juga mensyaratkan bahwa tanaman dan hasil panen perlu dicuci untuk melenyapkan embun sehingga menambah beban/biaya produksi bagi petani. Masalah berikutnya adalah status sebagai vektor untuk penyakit tanaman. Kutu kebul seringkali sebagai pengantar virus pembawa penyakit, seperti virus mosaic kuning (yellow masaic virus) atau virus gemini yang menular dan merusak tanaman terutama daun. Virus vektor ini sering sekali menyerang tanaman budidaya penting seperti tomat, selada, singkong, dan lain-lain.

Penelitian tentang biotipe $B$ tabaci telah banyak dilakukan di beberapa Negara eropa di Indonesia informasi mengenai biologi $B$ tabaci biotipe-B masih terbatas oleh karena itu penelitian mengenai neraca kehidupan $B$. tabaci biotipe-B pada tanaman cabai penting dilakukan. Menurut Stansly \& Naranjo, (2010) bentuk neraca kehidupan merupakan metode untuk menggambarkan dan mengukur kematian dalam suatu populasi maka diharapkan pengujian neraca kehidupan dapat menjadi informasi dalam pengambilan keputusan untuk mengendlikan populasi B. tabaci di lapangan. Tujuan penelitian ini adalah memberikan informasi neraca kehidupan hama Bemisia tabaci pada tanaman cabai.

\section{BAHAN DAN METODE}

Penelitian ini dilaksanakan di Laboratorium Fakultas Pertanian, Universitas Muhammadiyah Sumatera Utara, Medan pada Januari sampai Februari 2020.

\section{Persiapan Pengujian Perbanyakan Serangga}

Perbanyakan diawali dengan menginvestasikan imago atau pupa B. tabaci dari lapangan kedalam kurungan serangga, dengan tanaman tomat dan kapas sebagai inangnya. Setelah satu bulan populasi imago B. tabaci dalam kurungan digunakan sebagai bahan pengujian.

\section{Persiapan Tanaman Uji}

Tanaman yang digunakan dalam pengujian ini adalah tanaman cabai varietas Keriting Bogor umur tiga bulan. Pemilihan jenis tanaman uji didasarkan pada jenis tanaman yang umumnya banyak diserang $B$. tabaci dan dapat menjadi inang utama atau alternatif $B$. tabaci dilapangan, sedangkan pemilihan umur tanaman didasarkan pada kesiapan tanaman untuk diujikan, yaitu tanaman tidak terlalu muda tetapi juga belum berbunga.

\section{Pengujian Neraca Kehidupan}

Pengujian neraca kehidupan pada tanaman diawali dengan memasukkan 15 individu imago B. tabaci (5 jantan dan 10 betina) ke dalam tabung plastik mika berbentuk silinder yang bagian atasnya dilapisi kain kasa dan pada bagian tengahnya 
terdapat lubang yang berfungsi untuk memasukkan imago tersebut dan setelah 24 jam, imago dikeluarkan dari tabung. Setiap tanaman uji terdiri dari 3 ulangan dan banyaknya telur yang diamati pada setiap ulangan adalah 50 telur, sehingga total populasi awal pada setiap jenis tanaman uji dalam suatu suhu adalah 150 telur. Imago yang dihasilkan dari telur tersebut dipindahkan ke tanaman lain yang sama dengan inang sebelumnya, setiap kurungan hanya berisi satu imago (baik jantan maupun betina). Pengujian dilakukan pada suhu $25^{\circ} \mathrm{C}$ dan $29^{\circ} \mathrm{C}$ didalam growth chamber.

\section{HASIL DAN PEMBAHASAN}

Hasil penelitian ini dapat disajikan pada Gambar 1. Tanaman cabai diberikan sungkup yang didalamnya ada tanaman cabai dan kutu putih/kebul dalam sungkup. Kutu kebul merupakan hama yang sangat polifag dapat menyerang berbagai tanaman cabai, dan gulma. Hama ini sangat banyak dan tersebar di seluruh dunia, dapat hidup tropis ataupun subtropis, Morfologi telur Bemisia tabaci berbentuk elips dengan panjang sekitar 0,2-0,3 mm. Telur dimasukkan kedalam jaringan tanaman. Telur diletakkan di permukaan bawah daun. Stadia telur tergantung dengan keadaan lingkungan, terutama suhu. Pada suhu dari $26-32^{\circ} \mathrm{C}$ masa inkubasi berlangsung selama 4-6 hari, sedangkan pada suhu $18-22^{\circ} \mathrm{C}$ meningkat menjadi $10-16$ hari. Serangga betina lebih menyukai daun yang telah terinfeksi virus mosaik kuning sebagai tempat untuk meletakkan telurnya daripada daun sehat. Rata-rata banyaknya telur yang diletakkan pada daun yang terserang virus adalah 77 butir, sedangkan pada daun sehat hanya 14 butir. Hal ini sesuai dengan penelitian Subagyo \& Hidayat, (2014) bahwa hama kutu kebul pada tanaman cabai dengan suhu $29^{\circ} \mathrm{C}$ memiliki siklus dan lama hidup yang lebih singkat (21,04 dan 27,00 hari) dibandingkan dengan suhu $25^{\circ} \mathrm{C}$ (24,96 dan 31,21 hari). Hidayat et al., (2017) melaporkan bahwa hama kutu kebul (Bemisia tabaci) biotipe B memiliki siklus hidup dan lama hidup imago betina pada tanaman cabai masing-masing sebesar 33,27 dan 20,70 hari.

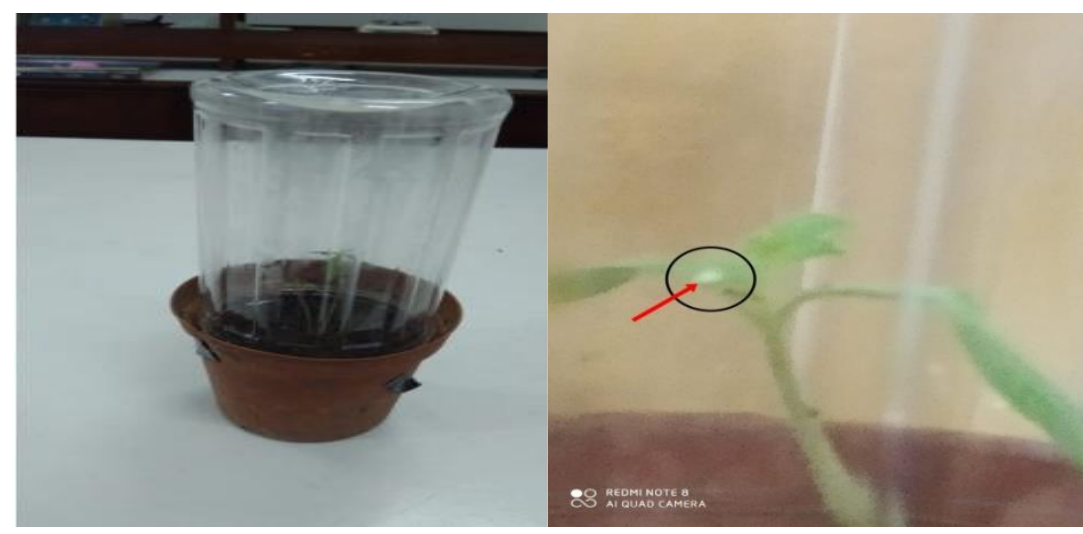

Gambar 1. Bemisia tabaci pada tanaman cabai. (Sumber: Dokumen Pribadi)

Pertumbuhan spesies harus mengetahui jumlah keturunan yang dihasilkan oleh seekor betina pada interval umur selama hidup dan jumlah individu pada setiap interval umur. Untuk mengetahui hal tersebut pendekatannya dengan mengikuti betina dalam 
satu populasi. Populasi betina dan perbandingan kelaminnya diketahui maka dengan mudah diketahui populasi jantan dan populasi total. Jika x melambangkan umur individu pada setiap periode dan setiap bagian populasi serangga betina dalam kohort yang dapat bertahan hidup pada umur tersebut dilambangkan dengan Ix maka statistik dari serangga dapat ditabulasi dari nilai Ix dibuat kurva bertahan hidup.

\section{KESIMPULAN}

Kutu kebul berwarna putih yang melengkat di sungkup berasal dari tanaman cabai memiliki morfologi panjang sekitar 0,2-0,3 mm. Telur dimasukkan ke dalam jaringan tanaman. Telur dibawah daun pada suhu $26-32^{\circ} \mathrm{C}$ masa inkubasi berlangsung selama 46 hari, sedangkan pada suhu $18-22^{\circ} \mathrm{C}$ meningkat menjadi $10-16$ hari.

\section{UCAPAN TERIMAKASIH}

Peneliti mengucapkan terima kasih kepada Universitas Muhammadiyah Sumatera Utara (UMSU) melalui Program Penelitian Dosen Pemula (PDP) Dana APB UMSU Tahun Anggaran 2019/2020 dengan No:71/II.3-AU/UMSU-LP2M/C/2020 yang telah mendanai penelitian ini.

\section{DAFTAR PUSTAKA}

Hidayat, P., Kurniawan, H. A., Afifah, L., \& Triwidodo, H. (2017). Siklus hidup dan statistik demografi kutukebul Bemisia tabaci (Gennadius) (Hemiptera: Aleyrodidae) biotipe B dan non-B pada tanaman cabai (Capsicum annuum L.). Jurnal Entomologi Indonesia, 14(3), 143-151. http://dx.doi.org/10.5994/jei.14.3.143.

Nawangsih, A. (2003). Cabai hot beauty (Edisi Revisi). Jakarta: Penebar Swadaya.

Price. (2007). Insect ecology. New York: John Wiley.

Simala. (2009). Whitefly species (Hemiptera: Aleyrodidae) recorded on imported ornamental plant in Croatia. In Proceedings of The $9^{\text {th }}$ Interantional Symposium on Plant Protection (pp. 389-396). Croatia: Plant Protection.

Stansly, P. A., \& Naranjo, S. E. (2010). Bemisia: bionomics and management of a global pest. Springer Science \& Business Media. https://doi.org/10.1007/97890-481-2460-2.

Subagyo, V. N. O., \& Hidayat, P. (2015). Neraca kehidupan kutukebul Bemisia tabaci (Gennadius) (Hemiptera: Aleyrodidae) pada tanaman cabai dan gulma babadotan pada suhu $25^{\circ} \mathrm{C}$ dan $29^{\circ} \mathrm{C}$. Jurnal Entomologi Indonesia, 11(1), 1118. http://dx.doi.org/10.5994/jei.11.1.11.

Sudiono. (2003). Deteksi symtomolgy dan teknik PCR virus gemini asal tanaman tomat. Jurnal Agritek, 11(4), 537-544.

Suharto. (2007). Pengenalan dan pengendalian hama tanaman pangan. Yogyakarta: Andi.

Tarigan, S., \& Wiryanta, W. (2003). Bertanam cabai hibrida secara intensif. Jakarta: Agromedia Pustaka.

Tindall, H. (1983). Vegetable in the tropics. London: Mac Milan Press Ltd. 